\title{
Hormonal treatment before and after artificial insemination differentially improves fertility in subpopulations of dairy cows during the summer and autumn
}

\author{
E. Friedman, ${ }^{*}$ H. Voet, † D. Reznikov, $₫$ D. Wolfenson, ${ }^{*}$ and Z. Roth ${ }^{\star 1}$ \\ *Department of Animal Science, and \\ †Department of Agriculture Economic and Management, Faculty of Agriculture, Food and Environment, the Hebrew University, Rehovot 76100 , \\ Israel \\ ‡Hachakleit Veterinary Services, Caesarea 38900, Israel
}

\section{ABSTRACT}

Reduced conception rate (CR) during the hot summer and subsequent autumn is a well-documented phenomenon. Intensive use of cooling systems can improve summer and autumn reproductive performance, but is unable to increase $\mathrm{CR}$ to winter and spring levels. We examined whether combined hormonal treatments - to increase follicular turnover before artificial insemination (AI) and progesterone supplementation post-AImight improve fertility of cooled cows during the summer and autumn. The experiment was conducted from July to November in 3 commercial herds in Israel and included 707 Holstein cows at 50 to $60 \mathrm{~d}$ in milk (DIM). Cows were hormonally treated to induce 2 consecutive 9-d cycles, with GnRH administration followed by $\mathrm{PGF}_{2 \alpha}$ injection $7 \mathrm{~d}$ later, followed by an intravaginal insert containing progesterone on $\mathrm{d} 5 \pm 1$ post-AI for $14 \mathrm{~d}$. Both untreated controls $(\mathrm{n}=376)$ and treated cows $(\mathrm{n}=331)$ were inseminated following estrus, and pregnancy was determined by palpation 42 to $50 \mathrm{~d}$ post-AI. First-AI CR data revealed a positive interaction between treatment and cows previously diagnosed with postpartum uterine disease [odds ratio (OR) 2.24]. Interaction between treatment and low body condition score tended to increase the probability of first-AI CR (OR 1.95) and increased pregnancy rate at 90 DIM (OR 2.50) and at 120 DIM (OR 1.77). Low milk production increased the probability of being detected in estrus at the end of synchronization within treated cows (OR 1.67), and interacted with treatment to increase probability of pregnancy at 90 DIM (OR 2.39) relative to control counterparts. It is suggested that when administered with efficient cooling, combined hormonal treatment in specific subgroups of cows, that is, those previously diagnosed with postpartum uterine disease

Received January 5, 2014.

Accepted September 9, 2014.

${ }^{1}$ Corresponding author: roth@agri.huji.ac.il or those with low body condition score or low milk yield might improve fertility during the summer and autumn. Integration of such an approach into reproductive management during the hot seasons might improve treatment efficiency and reduce expenses.

Key words: heat stress, fertility, hormonal treatment

\section{INTRODUCTION}

Fertility of high-lactating cows during the hot season is greatly reduced because of deleterious effects of heat stress on the reproductive tract (Wolfenson et al., 2000). The mechanism underlying this reduction in fertility is multifactorial in nature and includes impairment of ovarian-follicle function and steroid production, disruption of oocyte competence and embryonic development, attenuation of gonadotropin secretion, and functional impairment of the utero-embryonic unit (Wolfenson et al., 2000; Roth, 2008). In particular, exposing dairy cows to summer heat stress has long-lasting disruptive effects on the ovarian pool of follicles and their enclosed oocytes which last from the summer through the autumn (Roth et al., 2001, 2004). In addition, alterations in corpus luteum function have been reported during the summer, characterized by reduced progesterone $\left(\mathbf{P}_{4}\right)$ production by the corpus luteum (Wolfenson et al., 2000). Low $\mathrm{P}_{4}$ concentration during the luteal phase is associated with poor embryonic development and reduced interferon-tau production (Green et al., 2005), as well as elevated endometrial prostaglandin secretion and luteolysis (Mann et al., 1999). Such alterations might explain in part the low conception rate $(\mathbf{C R})$ of lactating cows during the summer and autumn (Zeron et al., 2001).

Various cooling systems are widely used in dairy farms to alleviate the effects of summer heat stress, resulting in a prominent increase in milk production to a level similar to that in winter. Nevertheless, the ability of these cooling systems to prevent the negative effects on reproductive performance is limited (De Ren- 
sis and Scaramuzzi, 2003). For instance, Israeli dairy farms practicing intensive cooling management had a summer-to-winter milk-production ratio of 0.985 , but CR was lower by 22 percentage units during the summer compared with that in the winter (Flamenbaum and Galon, 2010). Given the low efficiency of hormonal treatments at improving fertility of hyperthermic cows (Jordan, 2003), effective cooling seems to be a prerequisite for hormonal treatments' improvement of summer fertility in lactating cows.

We recently examined 2 hormonal approaches to improving the fertility of lactating cows during the summer and autumn. The first was based on the understanding that heat stress affects the ovarian pool of oocytes and that removal of the impaired follicle might alleviate, to some extent, the carryover effect of summer thermal stress (Roth, 2008). In fact, administration of GnRH followed by $\mathrm{PGF}_{2 \alpha}$ to induce 3 successive $9-\mathrm{d}$ cycles, thereby accelerating ovarian follicular turnover, was found to improve fertility of certain subgroups of cows during the summer and autumn: CR of primiparous cows increased by 16 percentage units, and pregnancy rate (PR) of cows with high BCS increased by 14 percentage units (Friedman et al., 2011). The second approach was based on insertion of a controlled intravaginal drug-releasing (CIDR) device containing $\mathrm{P}_{4}$ to support the developing embryo. Results showed that CIDR insertion $5 \mathrm{~d}$ after $\mathrm{AI}$ improves summer and autumn CR in the subgroup of cows with low BCS (Friedman et al., 2012). Given the multifactorial effect of heat stress on the reproductive system and in light of the differential effects of these 2 hormonal approaches (Friedman et al., 2011, 2012), we hypothesized that combining the 2 treatments might have a cumulative effect and expand the subpopulations of cows affected by one of the treatments alone. The study was carried out on dairy farms equipped with efficient cooling systems and utilizing intensive cooling management. Data were analyzed in relation to potential risk factors associated with reduced fertility, including BCS, parity, postpartum uterine disease, milk yield, and SCC.

\section{MATERIALS AND METHODS}

\section{Animals and Data Collection}

The study was conducted in 3 commercial dairy herds located in the coastal plain of Israel, in accordance with the guidelines of the ethics committee of the Hebrew University. Holstein dairy cows that calved between May and September were included in the study. A power analysis was performed to calculate the sample sizes needed to achieve $80 \%$ power at a $5 \%$ significance level. For a change of 10 percentage units in CR, 357 cows were needed per group when the control CR was $30 \%$, and 378 cows per group were needed when the control CR was $35 \%$.

Cows were housed in open sheds, milked 3 times daily, and fed TMR containing $1.7 \mathrm{NE}_{\mathrm{L}} \mathrm{Mcal} / \mathrm{kg}$ of DM, $16.5 \%$ protein and $32 \%$ NDF. Cows were subjected to similar routine veterinary health management, with diagnosis and treatment for postpartum diseases starting on d 5 to 12 postpartum and continuing through early lactation until recovery. Retained placenta was defined as the presence of fetal membranes $24 \mathrm{~h}$ after calving. Metritis and endometritis were diagnosed according to the character of the vaginal discharge and uterus tone and consistency, as previously described (Goshen and Shpigel, 2006). Cows with retained placenta, metritis, or endometritis were defined as having postpartum uterine disease and treated with intrauterine antibiotics until the clinical signs disappeared. Body condition score was evaluated by the veterinarian on a 5-point scale (Wildman et al., 1982) after parturition and at peak lactation (i.e., 50 to 60 DIM). Cows that were not detected in estrus by 50 DIM were defined as acyclic. Estrous behavior was detected by computerized pedometric system (SAE, Afikim, Israel) and visual observation. Insemination was based on heat detection.

Milk production was recorded monthly and SCC was analyzed by the Central Laboratory for Milk Recording of the Israeli Cattle Breeders Association (Caesarea, Israel). The milking records coinciding with the experimental period (i.e., second to fourth monthly milk tests postpartum) were used for data analysis. Farms were divided according to their summer-to-winter ratio of milk production (Flamenbaum and Galon, 2010). Those with a ratio $\geq 0.97$ were defined as having good management and those with a ratio of 0.93 to 0.95 were defined as having fair management.

\section{Cooling Management and Temperature Measurements}

Intensive cooling management was a prerequisite for the current study. The cooling was based on ventilation of the open sheds $(24 \mathrm{~h})$ and frequent intermittent cooling periods with fans and sprinklers in the holding area and along the feeding lines (Berman and Wolfenson, 1992). Cows were cooled in the holding area 3 times a day before milking and 2 to 3 additional times between milking. Cooling was operated along the feeding lines when cows returned from the milking parlor and after feed distribution. Overall, cows were exposed to approximately $6 \mathrm{~h} / \mathrm{d}$ of intensive cooling.

Records of air temperature and relative humidity were taken from stations located within $20 \mathrm{~km}$ of the farms. The mean minimal and maximal air tempera- 
tures and relative humidity during the summer (July to September) were 21.4 and $31.0^{\circ} \mathrm{C}$, and 54 and $90 \%$, respectively. The mean minimal and maximal air temperatures and relative humidity in the autumn (October to November) were 12.8 and $24.5^{\circ} \mathrm{C}$, and 43 and $88 \%$, respectively. In addition, a portable device (model number 45158, Extech Instruments Corp., Waltham, MA) was used to record air temperature and relative humidity on the farm. To evaluate the effectiveness of the cooling management and whether cows maintained normothermia, rectal temperatures of random cows (10 to 15 cows per measurement point) were taken on a representative summer day using a digital thermometer (Toshiba, Tokyo, Japan).

\section{Experimental Protocol}

A schematic illustration of the experimental protocol is presented in Figure 1. Cows at 50 to 60 DIM were examined by the herd veterinarian and randomly assigned to control or treatment groups. Control cows were inseminated following spontaneous estrus. Treated cows were injected i.m. with synthetic GnRH analog (200 $\mu \mathrm{g}$ gonadorelin, Gonabreed, Parnell Laboratories, Alexandria, Australia) followed by an injection with $\mathrm{PGF}_{2 \alpha}$ analog $(500 \mu \mathrm{g}$ cloprostenol, Estroplan, Parnell Laboratories) $7 \mathrm{~d}$ later. Similar administration of $\mathrm{GnRH}-\mathrm{PGF}_{2 \alpha}$ was repeated $2 \mathrm{~d}$ later to induce a second successive follicular wave. Treated cows that were detected in estrus within $5 \mathrm{~d}$ of the second $\mathrm{PGF}_{2 \alpha}$ injection were defined as normal-responding cows; treated cows detected in estrus more than $5 \mathrm{~d}$ after the end of the treatment were defined as late-responding cows. Cows were inseminated in the morning of the estrus day (d 0) or on the following day (d 1) when estrus was manifested in the p.m. hours. Cows received a CIDR insert containing $1.9 \mathrm{~g}$ of $\mathrm{P}_{4}$ (Eazi-Breed CIDR Cattle Insert, Pfizer Animal Health, New York, NY) on d $5 \pm 1$ post-AI, for $14 \mathrm{~d}$. Artificial insemination was carried out by a professional technician from the local AI services. Control and treatment cows that had not been inseminated by 90 DIM were checked and treated by the veterinarian according to the routine protocol of the veterinary service Hachaklait (Caesarea, Israel). Pregnancy determination was performed by rectal palpation at 42 to $50 \mathrm{~d}$ post-AI. Cows found not to be pregnant were rechecked after $7 \mathrm{~d}$ but did not undergo resynchronization.

\section{Statistical Analysis}

Days from calving to first AI, calving number, BCS, proportion of healthy cows, and milk yield were analyzed by one-way ANOVA using JMP version 7.0 (SAS Institute Inc., Cary, NC). Data are presented as means \pm SEM.

Multiple logistic regression (SAS 9.1, SAS Institute) was used to model the probability of first-AI CR

\section{Control}

Estrus Detection \& AI

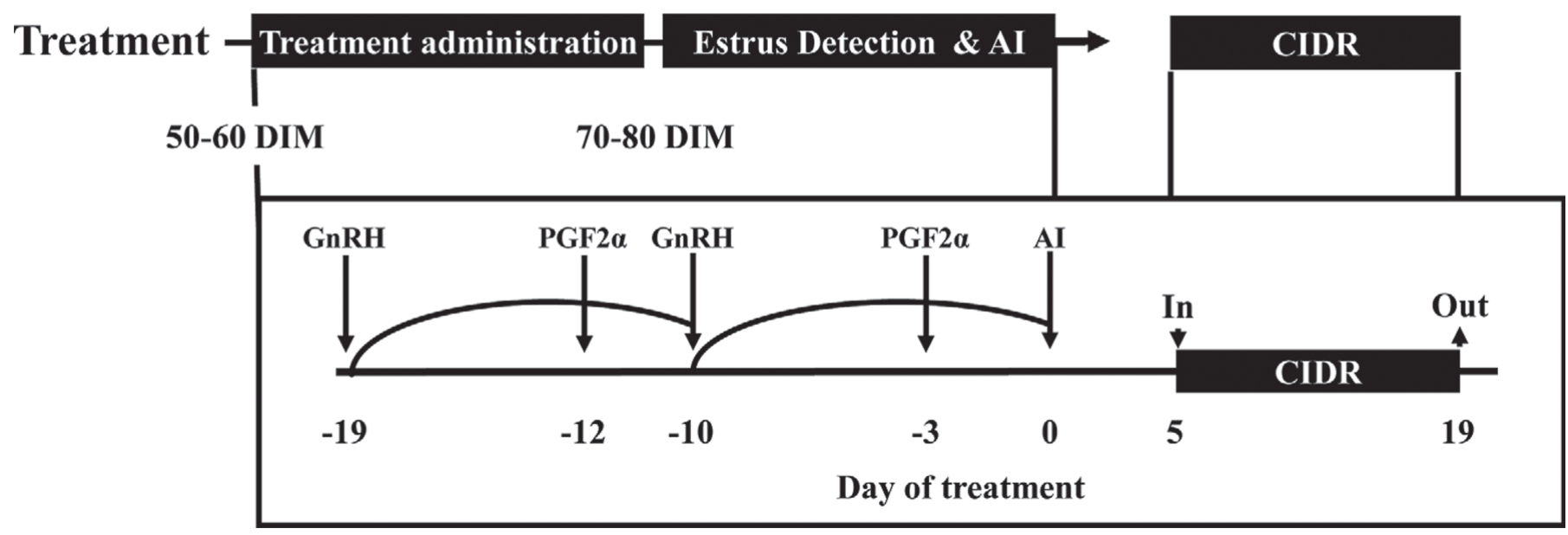

Figure 1. Schematized experimental protocol. Cows 50-60 DIM were assigned to control or treatment groups. Control cows received AI following spontaneous estrus, starting from 70 to 80 DIM. Treated cows were administered with GnRH injection followed by PGF $2 \alpha \mathrm{d}_{\text {later. }}$ A similar round of $\mathrm{GnRH}-\mathrm{PGF}_{2 \alpha}$ administration was repeated $2 \mathrm{~d}$ after that. Treatment cows were artificially inseminated at estrus $(\mathrm{d}=0)$ and received a controlled intravaginal drug-releasing (CIDR) insert containing progesterone on $\mathrm{d} 5 \pm 1$ for $14 \mathrm{~d}$. 
(number of pregnancies divided by number of 1st $\mathrm{AI}$ ) and PR (number of pregnancies at 90 DIM [PR 90] and 120 DIM [PR 120] divided by total number of cows). The following variables and their interactions with treatment were considered in a backward stepwise procedure for the $\mathrm{CR}$ model: parity (primiparous vs. multiparous), farm (fair vs. good management), BCS at peak lactation (cutoff at $\leq 2.25$ ), change in BCS between calving and peak lactation (cutoff at $\leq 0.50$ ), milk yield (cutoff at median; 48 and $36.7 \mathrm{~kg} / \mathrm{d}$ for multiparous and primiparous cows, respectively), season of AI [summer (July to September) vs. autumn (October to November)], postpartum uterine diseases, SCC (cutoff at $>150,000$ cells $/ \mathrm{mL}$ milk), interval between calving and first AI, and cyclicity status at 50 DIM (cyclic vs. acyclic). Variables included in the final model and presented were those passing the retention criteria set at $P<0.15$ and the associated main effects. Additional analysis was performed for CR using the same variables and the same retention criteria to model the probability of $\mathrm{CR}$ in the population of primiparous cows. To model the probability of PR 90 and PR 120, calving time [early summer (May to July) vs. late summer (August and September)] was considered in the backward stepwise procedure with the aforementioned variables, excluding season of AI and interval between calving and first AI. Variables were considered, as previously, by the use of a backward stepwise procedure with entry criteria set at $P<0.15$.

The same retention criteria were used to model response success to treatment with regard to timing of estrus. The variables considered in the backward stepwise procedure were those used for the PR models and, in addition, the interval between calving and second $\mathrm{PGF}_{2 \alpha}$ injection. Treated cows that were detected in estrus within $5 \mathrm{~d}$ from the second $\mathrm{PGF}_{2 \alpha}$ injection were defined as normal-responding cows; cows detected in estrus more than $5 \mathrm{~d}$ after the end of treatment were defined as late-responding cows.

Using time to conception as the outcome variable, survival analysis was performed to compare treatment effects. Each cow contributed to the analysis for a maximum of $150 \mathrm{~d}$. Observations were excluded when a cow was culled or excluded from breeding.

\section{RESULTS}

A total of 800 cows were included in the study. Of these, 59 cows ( 31 controls and 28 treated cows) were culled before pregnancy determination or diagnosed with unrecoverable uterine diseases at the time of treatment initiation, and were therefore excluded from the analysis. An additional 34 cows did not complete the entire treatment, and were therefore excluded from the analysis. Overall, 376 control cows (231 multiparous, 145 primiparous) and 331 treatment cows (201 multiparous, 130 primiparous) were included in the final analysis for a total of 707 cows. Of these, 3 cows were not inseminated by 150 DIM, and therefore were not included in the first-AI CR analysis. In addition, 7 cows were culled or excluded from breeding before 120 DIM, and therefore were not included in the PR 120 analysis.

The following variables did not differ between experimental groups (control and treatment groups, respectively): calving number $(2.2 \pm 0.1$ and $2.3 \pm 0.1 ; P=$ $0.48)$, average milk yield (43.4 \pm 0.4 and $43.9 \pm 0.4$ $\mathrm{kg} / \mathrm{d} ; P=0.45), \mathrm{BCS}$ at calving $(3.0 \pm 0.03$ and $3.0 \pm$ $0.03 ; P=0.98)$ and BCS at peak lactation $(2.4 \pm 0.03$ and $2.4 \pm 0.03 ; P=0.91)$. In addition, the proportion of cows with postpartum uterine diseases (43 and 39\%; $P=0.24)$, high SCC (36 and $40 \% ; P=0.27)$, that were acyclic at 50 DIM (36 and $34 \% ; P=0.42$ ), calving in early summer ( 56 and $55 \% ; P=0.76)$, and inseminated during the summer (37 and $38 \% ; P=0.78$ ) did not differ between experimental groups (control and treatment groups, respectively).

\section{Environmental Temperature and Body Temperature}

The average daily rectal temperatures on a representative measurement day were $38.9 \pm 0.05,38.7 \pm 0.1$, and $39.1 \pm 0.07^{\circ} \mathrm{C}$ (for farms A, B, and C, respectively; $P<0.05)$. Air temperature, relative humidity, and temperature humidity index on the measurement days were $28.6 \pm 0.2^{\circ} \mathrm{C}, 69.7 \pm 0.9 \%$, and $79.2 \pm 0.2$ (farm A); $29.0 \pm 0.2^{\circ} \mathrm{C}, 64.0 \pm 1.3 \%$, and $79.0 \pm 0.4$ (farm B); and $28.7 \pm 0.5^{\circ} \mathrm{C}, 68.0 \pm 1.8 \%$, and $79.2 \pm 0.4$ (farm C), respectively.

\section{Reproductive Parameters}

Days open for pregnant cows at 90 DIM $(78.1 \pm 0.8$ vs. $77.9 \pm 0.6)$ and 120 DIM $(89.6 \pm 1.1$ vs. $88.5 \pm 1.2)$ did not differ between control and treatment groups, respectively. Days to first AI were higher by $4 \mathrm{~d}$ for control compared with treated cows $(86.3 \pm 1.1$ vs. 81.9 \pm 0.7 , respectively; $P<0.01$ ).

The logistic regression to model first AI CR is presented in Table 1. The probability of conceiving was lower for multiparous cows $(P<0.001)$, farms with fair management $(P<0.007)$, and acyclic cows $(P<0.005)$. Autumn first-AI CR was greater by 6 percentage units than that of summer $(P=0.049)$. Analysis revealed that none of the aforementioned parameters interacted with treatment. On the other hand, treatment improved first-AI CR in cows previously diagnosed with postpartum uterine disease $(P=0.047)$, reflected by a 10 percentage unit increase in first-AI CR of treated 
Table 1. Effect of combined hormonal treatment on first-AI conception rate during the summer and autumn in cows subjected to an efficient cooling management ${ }^{1}$

\begin{tabular}{|c|c|c|c|c|}
\hline Item & $\begin{array}{c}\text { Actual } \\
\text { conception rate, } \\
\%(n / n)\end{array}$ & $\begin{array}{c}\text { Adjusted } \\
\text { odds ratio }\end{array}$ & $95 \% \mathrm{CI}$ & $P$-value \\
\hline Treatment & $36(118 / 330)$ & 1.21 & $(0.58,2.54)$ & 0.605 \\
\hline Control & $34(127 / 374)$ & Referent & & \\
\hline \multicolumn{5}{|l|}{ Parity } \\
\hline Multiparous & $28(120 / 431)$ & 0.48 & $(0.34,0.68)$ & $<0.001$ \\
\hline Primiparous & $46(125 / 273)$ & Referent & & \\
\hline \multicolumn{5}{|l|}{ Farm $^{2}$} \\
\hline Fair & $33(146 / 440)$ & 0.59 & $(0.40,0.87)$ & 0.007 \\
\hline Good & $38(99 / 264)$ & Referent & & \\
\hline \multicolumn{5}{|l|}{ Cyclic at $50 \mathrm{DIM}^{3}$} \\
\hline No & $26(64 / 246)$ & 0.59 & $(0.41,0.85)$ & 0.005 \\
\hline Yes & $40(181 / 458)$ & Referent & & \\
\hline \multicolumn{5}{|l|}{ Season of AI } \\
\hline Autumn & $37(162 / 439)$ & 1.62 & $(1.00,2.63)$ & 0.049 \\
\hline Summer & $31(83 / 265)$ & Referent & & \\
\hline Autumn-treatment & $36(74 / 204)$ & 0.68 & $(0.37,1.26)$ & 0.224 \\
\hline Autumn-control & $37(88 / 235)$ & Referent & & \\
\hline Summer-treatment ${ }^{4}$ & $35(44 / 126)$ & 2.19 & $(0.90,5.31)$ & 0.082 \\
\hline Summer-control $^{4}$ & $28(40 / 144)$ & Referent & & \\
\hline \multicolumn{5}{|l|}{ Body condition score ${ }^{5}$} \\
\hline Low & $28(95 / 344)$ & 0.42 & $(0.26,0.69)$ & $<0.001$ \\
\hline High & $42(147 / 354)$ & Referent & & \\
\hline Low-treatment & $31(51 / 162)$ & 1.95 & $(0.92,4.12)$ & 0.081 \\
\hline Low-control & $24(44 / 182)$ & Referent & & \\
\hline High-treatment ${ }^{4}$ & $40(64 / 162)$ & 0.77 & $(0.35,1.69)$ & 0.514 \\
\hline High-control $^{4}$ & $43(83 / 192)$ & Referent & & \\
\hline \multicolumn{5}{|l|}{$\mathrm{SCC}^{6}$} \\
\hline High & $29(77 / 268)$ & 0.87 & $(0.53,1.41)$ & 0.562 \\
\hline Low & $39(168 / 436)$ & Referent & & \\
\hline High-treatment & $27(36 / 132)$ & 0.74 & $(0.33,1.64)$ & 0.460 \\
\hline High-control & $30(41 / 136)$ & Referent & & \\
\hline Low-treatment ${ }^{4}$ & $41(82 / 198)$ & 2.03 & $(0.96,4.26)$ & 0.062 \\
\hline Low-control $^{4}$ & $36(86 / 238)$ & Referent & & \\
\hline \multicolumn{5}{|l|}{ Uterine disease } \\
\hline Diagnosed & $31(89 / 291)$ & 0.63 & $(0.39,1.02)$ & 0.062 \\
\hline Healthy & $38(156 / 413)$ & Referent & & \\
\hline Diagnosed-treatment & $36(46 / 128)$ & 2.24 & $(1.01,4.98)$ & 0.047 \\
\hline Diagnosed-control & $26(43 / 163)$ & Referent & & \\
\hline Healthy-treatment ${ }^{4}$ & $36(72 / 202)$ & 0.67 & $(0.31,1.44)$ & 0.306 \\
\hline Healthy-control ${ }^{4}$ & $40(84 / 211)$ & Referent & & \\
\hline
\end{tabular}

${ }^{1}$ Treatment cows were treated with $\mathrm{GnRH}-\mathrm{PGF}_{2 \alpha}$ to induce two successive 9-d cycles before AI, followed by insertion of a controlled intravaginal drug-releasing insert containing progesterone, $5 \mathrm{~d}$ post-AI.

${ }^{2}$ Farms with a summer:winter milk-production ratio $\geq 0.97$ were defined as practicing good management and farms with a ratio of 0.93 to 0.95 were defined as practicing fair management.

${ }^{3}$ Determined by pedometer activity.

${ }^{4}$ Informative data based on converting the reference from the original model.

${ }^{5} \mathrm{BCS}>2.25$ at initiation of treatment was defined as high.

${ }^{6} \mathrm{High}$ SCC was defined as $>150,000$ cells/mL in one of the monthly milking records (second-fourth).

cows relative to their control counterparts. In addition, low BCS at peak lactation tended $(P=0.081)$ to interact with treatment, reflected by a 7 percentage unit increase in $\mathrm{CR}$ of treated cows relative to their control counterparts. Additional analysis of CR sorted by parity revealed that primiparous cows with high BCS difference, between calving and peak lactation, tended to interact with treatment (Table $2 ; P<0.067$ ).

The logistic regression to model PR 90 is presented in Table 3. Coinciding with first AI CR, probabilities of PR 90 were lower in multiparous cows $(P<0.003)$, farms with fair management $(P<0.017)$, and acyclic cows $(P<0.001)$. Calving in late summer increased the probability of PR $90(P=0.017)$ relative to calving in early summer. However, none of these variables interacted with treatment (Table 3 ). On the other hand, low BCS $(P=0.019)$ and low milk yield $(P=0.015)$ interacted with treatment, as reflected by a 12 percentage unit increase of PR 90 in these 2 subpopulations relative to their control counterparts (Table 3 ).

The logistic regression to model PR 120 is presented in Table 4. Coinciding with first AI CR and PR 90, 
Table 2. First-AI conception rate in primiparous cows during the summer and autumn; all cows were subjected to an efficient cooling management ${ }^{1}$

\begin{tabular}{|c|c|c|c|c|}
\hline BCS difference $^{2}$ & $\begin{array}{c}\text { Actual } \\
\text { conception rate } \\
\%(\mathrm{n} / \mathrm{n})\end{array}$ & $\begin{array}{l}\text { Adjusted } \\
\text { odds ratio }\end{array}$ & $95 \%$ CI & $P$-value \\
\hline High & $38(41 / 109)$ & 0.33 & $(0.16,0.68)$ & 0.003 \\
\hline Low & $53(81 / 153)$ & Referent & & \\
\hline High $\times$ Treatment & $39(22 / 56)$ & 2.76 & $(0.93,8.17)$ & 0.067 \\
\hline High $\times$ Control & $36(19 / 53)$ & Referent & & \\
\hline
\end{tabular}

${ }^{1}$ Treatment cows were treated with $\mathrm{GnRH}-\mathrm{PGF}_{2 \alpha}$ to induce two successive 9-d cycles before AI, followed by insertion of a controlled intravaginal drug-releasing insert containing progesterone, $5 \mathrm{~d}$ post-AI.

${ }^{2}$ High BCS difference was defined as losing $>0.5$ units between calving and peak lactation.

probabilities of PR 120 were lower in multiparous cows $(P<0.003)$, farms with fair management $(P<0.001)$, and acyclic cows $(P<0.001)$. Analysis revealed an interaction between treatment and low BCS $(P=0.053)$ and a tendency toward interaction between treatment and low milk yield $(P=0.098)$, as reflected by an 11 to 12 percentage unit increase of PR 120 relative to their control counterparts. Treatment interacted negatively with high SCC $(P=0.012)$, reflected by a 7 percentage unit decrease of PR 120 relative to control counterparts (Table 4).

Among the treated cows, about 65\% $(\mathrm{n}=226)$ were normal-responding (detected in estrus within $5 \mathrm{~d}$ from the second $\mathrm{PGF}_{2 \alpha}$ injection) and $35 \%(\mathrm{n}=123)$ were late-responding. Logistic regressions to model cows' responses to treatment revealed that of all examined variables; only low milk production increased the probability of a normal response (OR 1.67; $P=0.026$ ), as reflected by an 11 percentage unit increase compared with high-milk-production cows (data not shown). Acyclic cows tended to have a lower probability of a normal response (OR $0.64 ; P=0.063$ ), as reflected by an 8 percentage unit decrease in normal response compared with cyclic cows.

Survival analysis curves indicated that $\mathrm{PR}$ for cows with low BCS at treatment initiation (Figure 2A) was higher for treated cows relative to their control counterparts (log-rank test; $P=0.014)$. On the other hand, within cows with high BCS, PR did not differ between treated and control cows (Figure 2B). Survival analysis curves for the subgroup of cows with low milk production (Figure 3A), indicated that PR tended to be higher for treated cows relative to their control counterparts (log-rank test; $P=0.07$ ). On the other hand, within cows with high milk production, PR did not differ between treated and control cows (Figure 3B). Survival analysis curves for the subgroup of cows with postpartum uterine disease (Figure 4A), indicated that PR did not differ when cows contributed to the analysis $150 \mathrm{~d}$ and tended to be higher in the treated group relative to their control counterparts when cows contributed to the analysis $120 \mathrm{~d}$ (log-rank test; $P=0.086)$. On the other hand, within uninfected cows, PR did not differ between treated and control cows (Figure 4B).

\section{DISCUSSION}

Cooling systems are widely used in dairy farms to alleviate the effects of summer heat stress. However, their ability to prevent its negative effects on reproduction is limited. Moreover, hormonal treatments given alone are not efficient at improving the fertility of hyperthermic cows. The current study presents a combined approach to alleviating the deleterious effect of summer heat stress on the reproductive tissues, in particular, the ovarian pool of follicles, their enclosed oocytes, and the corpus luteum. Reduced fertility during the summer is a multifactorial problem and is thus in need of a potentially multifactorial solution; combining successive GnRH and $\mathrm{PGF}_{2 \alpha}$ administration before AI, followed by CIDR insertion after AI had a positive effect on reproductive performance in 3 subgroups of cows: those diagnosed with postpartum uterine disease, those with low BCS at peak lactation, and those with low milk yield. Integration of such an approach into reproductive management during the hot seasons might improve treatment efficiency and reduce expenses. It should be noted, however, that the positive effects reported here might not be limited to the hot season and might also be relevant to cows under normothermic conditions. This assumption requires further examination.

Adequate circulating $\mathrm{P}_{4}$ concentrations before AI, near the time of AI or following AI are highly important for fertility (Wiltbank et al., 2012). In particular, minor elevations in $\mathrm{P}_{4}$ near $\mathrm{AI}$ are associated with reduced fertility when insemination is based on estrus detection (Waldmann et al., 2001) and in repeat-breeding cows (Ghanem et al., 2006). In our previous study performed in the summer and autumn (Friedman et al., 2012), insertion of a CIDR post-AI as a sole treatment improved CR of cows with low BCS at peak lactation. This effect was intensified in the subgroup of cows with both low 
Table 3. Effect of combined hormonal treatment on pregnancy rate at 90 DIM during the summer and autumn in cows subjected to an efficient cooling management ${ }^{1}$

\begin{tabular}{|c|c|c|c|c|}
\hline Item & $\begin{array}{c}\text { Actual } \\
\text { pregnancy rate, } \\
\% \text { (no./no.) }\end{array}$ & $\begin{array}{l}\text { Adjusted } \\
\text { odds ratio }\end{array}$ & $95 \%$ CI & $P$-value \\
\hline Treatment & $30(100 / 331)$ & 1.19 & $(0.57,2.47)$ & 0.650 \\
\hline Control & $25(94 / 376)$ & Referent & & \\
\hline \multicolumn{5}{|l|}{ Parity } \\
\hline Multiparous & $23(98 / 432)$ & 0.57 & $(0.40,0.82)$ & 0.003 \\
\hline Primiparous & $35(96 / 275)$ & Referent & & \\
\hline \multicolumn{5}{|l|}{ Farm $^{2}$} \\
\hline Fair & $26(117 / 443)$ & 0.62 & $(0.42,0.92)$ & 0.017 \\
\hline Good & $29(77 / 264)$ & Referent & & \\
\hline \multicolumn{5}{|l|}{ Cyclic at $50 \mathrm{DIM}^{3}$} \\
\hline No & $17(43 / 248)$ & 0.47 & $(0.32,0.70)$ & $<0.001$ \\
\hline \multirow{2}{*}{\multicolumn{5}{|c|}{ Calving season }} \\
\hline & & & & \\
\hline Late summer & $31(98 / 316)$ & 1.85 & $(1.12,3.06)$ & 0.017 \\
\hline Early summer & $25(96 / 391)$ & Referent & & \\
\hline Late summer-treatment & $31(46 / 150)$ & 0.63 & $(0.30,1.30)$ & 0.207 \\
\hline Late summer-control & $31(52 / 166)$ & Referent & & \\
\hline Early summer-treatment ${ }^{4}$ & $30(54 / 181)$ & 2.60 & $(1.09,6.16)$ & 0.031 \\
\hline Early summer-control ${ }^{4}$ & $20(42 / 210)$ & Referent & & \\
\hline \multicolumn{5}{|l|}{ Body condition score ${ }^{5}$} \\
\hline Low & $23(79 / 345)$ & 0.42 & $(0.24,0.72)$ & 0.002 \\
\hline High & $31(112 / 356)$ & Referent & & \\
\hline Low-treatment & $29(47 / 162)$ & 2.50 & $(1.16,5.40)$ & 0.019 \\
\hline Low-control & $17(32 / 183)$ & Referent & & \\
\hline High-treatment ${ }^{4}$ & $31(50 / 163)$ & 0.65 & $(0.28,1.52)$ & 0.318 \\
\hline High-control $^{4}$ & $32(62 / 193)$ & Referent & & \\
\hline \multicolumn{5}{|l|}{$\mathrm{SCC}^{6}$} \\
\hline High & $25(68 / 269)$ & 1.27 & $(0.76,2.14)$ & 0.360 \\
\hline Low & $29(126 / 438)$ & Referent & & \\
\hline High-treatment & $25(33 / 133)$ & 0.61 & $(0.27,1.39)$ & 0.239 \\
\hline High-control & $26(35 / 136)$ & Referent & & \\
\hline Low-treatment ${ }^{4}$ & $34(67 / 198)$ & 2.67 & $(1.18,6.05)$ & 0.018 \\
\hline Low-control ${ }^{4}$ & $25(59 / 240)$ & Referent & & \\
\hline \multicolumn{5}{|l|}{ Milk yield $^{7}$} \\
\hline Low & $25(89 / 350)$ & 0.57 & $(0.34,0.94)$ & 0.029 \\
\hline High & $29(105 / 357)$ & Referent & & \\
\hline Low-treatment & $32(52 / 162)$ & 2.39 & $(1.19,4.81)$ & 0.015 \\
\hline Low-control & $20(37 / 188)$ & Referent & & \\
\hline High-treatment ${ }^{4}$ & $28(48 / 169)$ & 0.68 & $(0.30,1.55)$ & 0.358 \\
\hline High-control $^{4}$ & $30(57 / 188)$ & Referent & & \\
\hline
\end{tabular}

${ }^{1}$ Treatment cows were treated with $\mathrm{GnRH}-\mathrm{PGF}_{2 \alpha}$ to induce two successive 9-d cycles before AI, followed by insertion of a controlled intravaginal drug-releasing insert containing progesterone $5 \mathrm{~d}$ post-AI.

${ }^{2}$ Farms with a summer:winter milk-production ratio $\geq 0.97$ were defined as practicing good management and farms with a ratio of 0.93 to 0.95 were defined as practicing fair management.

${ }^{3}$ Determined by pedometer activity.

${ }^{4}$ Informative data based on converting the reference from the original model.

${ }^{5} \mathrm{BCS}>2.25$ at initiation of treatment was defined as high.

${ }^{6} \mathrm{High}$ SCC was defined as $>150,000$ cells/mL in one of the monthly milking records (second-fourth).

${ }^{7}$ High milk yield was defined by median (second, third, and fourth monthly milk tests).

BCS and postpartum uterine disease (i.e., treatment $x$ uterine disease $\times$ low BCS interaction). Here, we report an extended effect as the combined treatment improved fertility among a wider subgroup of cows previously diagnosed with uterine disease regardless of their BCS (i.e., treatment $\times$ uterine disease interaction). This finding is highly important for herd reproductive management because high proportions of calving cows are diagnosed with postpartum uterine diseases (Markus- feld et al., 1997; Goshen and Shpigel, 2006). Cows with postpartum uterine disease have delayed resumption of cyclicity and inferior reproductive performance (Fourichon et al., 2000; Opsomer et al., 2000; Sheldon et al., 2009b). It is possible therefore, that the successive $\mathrm{GnRH}-\mathrm{PGF}_{2 \alpha}$ administration in the current study improved cyclicity resumption in postpartum cows, as previously suggested by Souza et al. (2008). In this respect, it is important to note that in our previous study, 
Table 4. Effect of combined hormonal treatment on pregnancy rate at 120 DIM during the summer and autumn in cows subjected to an efficient cooling management ${ }^{1}$

\begin{tabular}{|c|c|c|c|c|}
\hline Item & $\begin{array}{c}\text { Actual } \\
\text { pregnancy rate, } \\
\%(\mathrm{n} / \mathrm{n})\end{array}$ & $\begin{array}{l}\text { Adjusted } \\
\text { odds ratio }\end{array}$ & $95 \% \mathrm{CI}$ & $P$-value \\
\hline Treatment & $50(164 / 325)$ & 0.96 & $(0.52,1.76)$ & 0.890 \\
\hline Control & $46(173 / 375)$ & Referent & & \\
\hline \multicolumn{5}{|l|}{ Parity } \\
\hline Multiparous & $42(181 / 426)$ & 0.60 & \multirow[t]{2}{*}{$(0.43,0.84)$} & \multirow[t]{2}{*}{0.003} \\
\hline Primiparous & $57(156 / 274)$ & Referent & & \\
\hline \multicolumn{5}{|l|}{ Farm $^{2}$} \\
\hline Fair & $45(198 / 436)$ & 0.51 & \multirow[t]{2}{*}{$(0.35,0.73)$} & \multirow[t]{2}{*}{$<0.001$} \\
\hline Good & $53(139 / 264)$ & Referent & & \\
\hline \multicolumn{5}{|l|}{ Cyclic at 50 DIM $^{3}$} \\
\hline No & $36(87 / 244)$ & 0.47 & \multirow[t]{2}{*}{$(0.34,0.66)$} & \multirow{2}{*}{$<0.001$} \\
\hline Yes & $55(250 / 456)$ & Referent & & \\
\hline \multicolumn{5}{|c|}{ Body condition score ${ }^{4}$} \\
\hline Low & $42(143 / 344)$ & 0.40 & \multirow[t]{2}{*}{$(0.25,0.63)$} & \multirow[t]{2}{*}{$<0.001$} \\
\hline High & $55(191 / 350)$ & Referent & & \\
\hline Low-treatment & $48(77 / 161)$ & 1.77 & \multirow{2}{*}{$(0.99,3.15)$} & \multirow{2}{*}{0.053} \\
\hline Low-control & $36(66 / 183)$ & Referent & & \\
\hline High-treatment ${ }^{5}$ & $53(84 / 158)$ & 0.70 & \multirow{2}{*}{$(0.36,1.34)$} & \multirow[t]{2}{*}{0.276} \\
\hline High-control $^{5}$ & $56(107 / 192)$ & Referent & & \\
\hline \multicolumn{5}{|l|}{$\mathrm{SCC}^{6}$} \\
\hline High & $44(116 / 266)$ & 1.24 & \multirow[t]{2}{*}{$(0.79,1.96)$} & \multirow[t]{2}{*}{0.347} \\
\hline Low & $51(221 / 434)$ & Referent & & \\
\hline High-treatment & $40(53 / 131)$ & 0.41 & \multirow[t]{2}{*}{$(0.20,0.82)$} & 0.012 \\
\hline High-control & $47(63 / 135)$ & Referent & & \multirow{3}{*}{$<0.001$} \\
\hline Low-treatment ${ }^{5}$ & $57(111 / 194)$ & 3.00 & \multirow[t]{2}{*}{$(1.58,5.71)$} & \\
\hline Low-control $^{5}$ & $46(110 / 240)$ & Referent & & \\
\hline \multicolumn{5}{|l|}{ Milk yield ${ }^{7}$} \\
\hline Low & $46(157 / 343)$ & 0.60 & \multirow[t]{2}{*}{$(0.39,0.93)$} & \multirow[t]{2}{*}{0.022} \\
\hline High & $50(180 / 357)$ & Referent & & \\
\hline Low-treatment & $52(81 / 156)$ & 1.63 & \multirow{2}{*}{$(0.91,2.90)$} & 0.098 \\
\hline Low-control & $41(76 / 187)$ & Referent & & \\
\hline High-treatment $^{5}$ & $49(83 / 169)$ & 0.75 & $(0.39,1.46)$ & 0.405 \\
\hline High-control $^{5}$ & $52(97 / 188)$ & Referent & & \\
\hline $\begin{array}{l}{ }^{1} \text { Treatment cows } \\
\text { insertion of contro }\end{array}$ & $\begin{array}{l}\mathrm{GnRH}-\mathrm{PGF}_{2 \alpha} \\
\text { cug-releasing in }\end{array}$ & $\begin{array}{l}\text { two suc } \\
\text { ining pr }\end{array}$ & $\begin{array}{l}\text {-d cycles bef } \\
\text { ne } 5 \text { d post- } A\end{array}$ & followed by \\
\hline $\begin{array}{l}{ }^{2} \text { Farms with a sum } \\
\text { farms with a ratio }\end{array}$ & $\begin{array}{l}\text { roduction ratic } \\
\text { re defined as pr }\end{array}$ & $\begin{array}{l}\text { vere define } \\
\text { fair manag }\end{array}$ & acticing good & agement and \\
\hline${ }^{3}$ Determined by pe & & & & \\
\hline${ }^{4} \mathrm{BCS}>2.25$ at init & nt was defined as & & & \\
\hline${ }^{5}$ Informative data & ing the reference & ne original $n$ & & \\
\hline${ }^{6}$ High SCC was de & cells $/ \mathrm{mL}$ in one & monthly mi & ecords (seco & th). \\
\hline${ }^{7}$ High milk yield & an; for multip & . & when th & 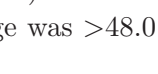 \\
\hline
\end{tabular}

administering successive $\mathrm{GnRH}-\mathrm{PGF}_{2 \alpha}$ injections alone did not have any beneficial effect on the fertility of cows diagnosed with postpartum uterine disease (Friedman et al., 2011).

The notion that successive $\mathrm{GnRH}-\mathrm{PGF}_{2 \alpha}$ administration improves first-AI CR in cows with postpartum uterine disease only when combined with CIDR post-AI is not clear-cut. Progesterone plays an important role in regulating the uterine inflammatory response. One of the proposed benefits of $\mathrm{PGF}_{2 \alpha}$ administration in cows diagnosed with uterine disease is related to removing the immunosuppressive effects of $\mathrm{P}_{4}$, thereby improving infection resolution (Kasimanickam et al., 2005). On the other hand, after fertilization, $\mathrm{P}_{4}$ inhibits immune function in the uterus, thereby increasing the probability of successful pregnancy (Hansen, 2013). Thus, it is possible that exogenous $\mathrm{P}_{4}$ reduces the ongoing inflammatory reaction in the uterus and increases the probability of embryo implantation in cows previously suffering from uterine infection. Collectively, it is suggested that although $\mathrm{GnRH}-\mathrm{PGF}_{2 \alpha}$ administration improves infection resolution before AI, insertion of a CIDR device post-AI increases $\mathrm{P}_{4}$ concentration and improves regulation of endometrial function.

The beneficial effect of hormonal administration to increase $\mathrm{P}_{4}$ post-AI is strongly associated with decreased $\mathrm{P}_{4}$ concentrations during summer heat stress (Wolfenson et al., 2002). This might also be the situ- 


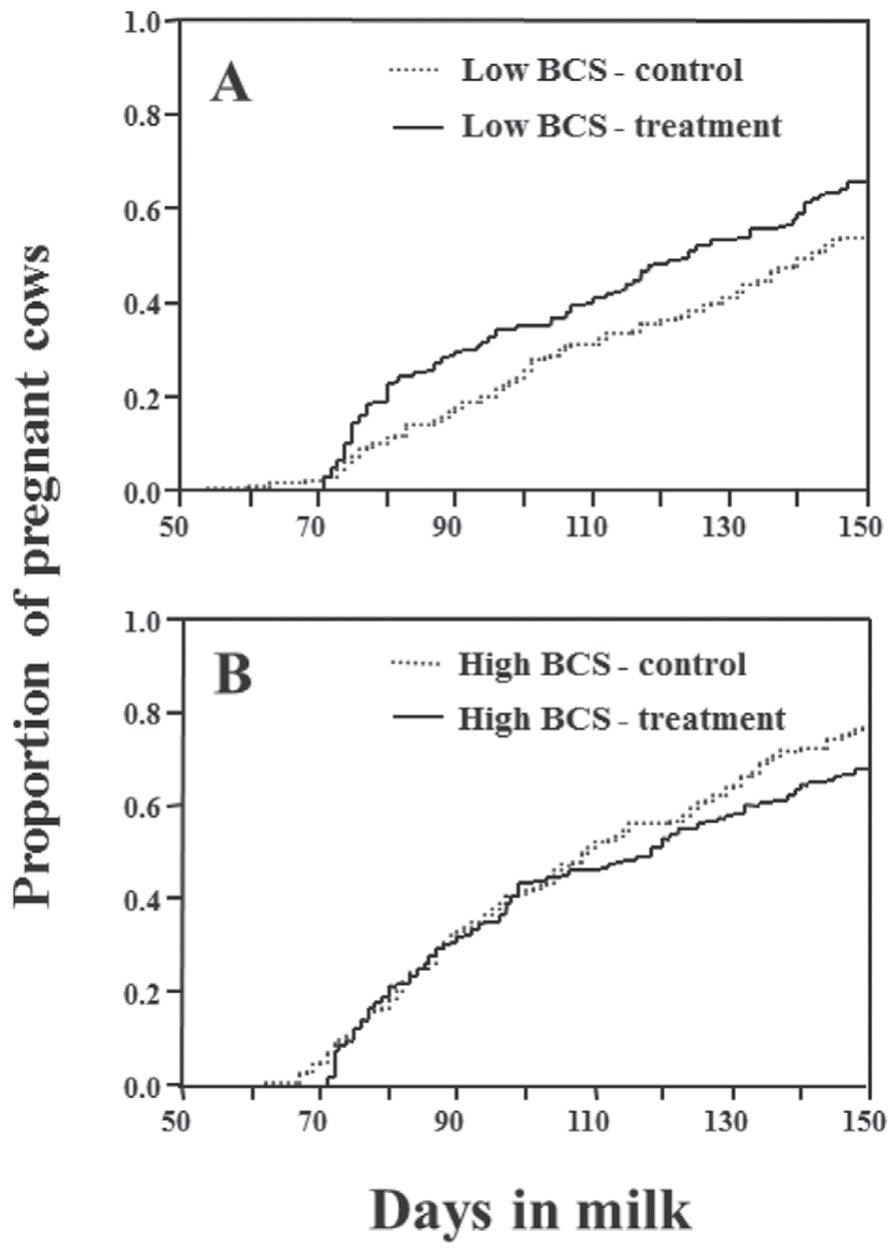

Figure 2. Survival curves for time to pregnancy. (A) Within the subgroup of cows with low BCS $(\leq 2.25)$ at initiation of treatment, pregnancy rate was higher for treated cows relative to their control counterparts (log-rank test; $P=0.014$ ). (B) Within cows with high BCS $(>2.25)$, pregnancy rate did not differ between treated and control cows.

ation during the autumn, because $\mathrm{P}_{4}$ production by follicular cells isolated from the preovulatory follicle is lower during the autumn than in winter (Wolfenson et al., 1997). In support of this, inserting a CIDR device on $\mathrm{d} 5$ post-AI improved $\mathrm{CR}$ in cows with low BCS in both summer and autumn (Friedman et al., 2012). An association between fertility, BCS, and $\mathrm{P}_{4}$ supplementation post-AI has also been reported under thermoneutral conditions. For instance, administration of human chorionic gonadotropin post-AI to increase $\mathrm{P}_{4}$ concentration markedly improved $\mathrm{CR}$ in cows with low BCS (Santos et al., 2001). In addition, Ovsynch treatment followed by $\mathrm{P}_{4}$ supplementation post-AI was found to be more effective in cows with high BCS (Forro et al., 2012). However, it is possible that the Ovsynch protocol played a confounding role, decreasing the probability for conception in cows with low BCS.

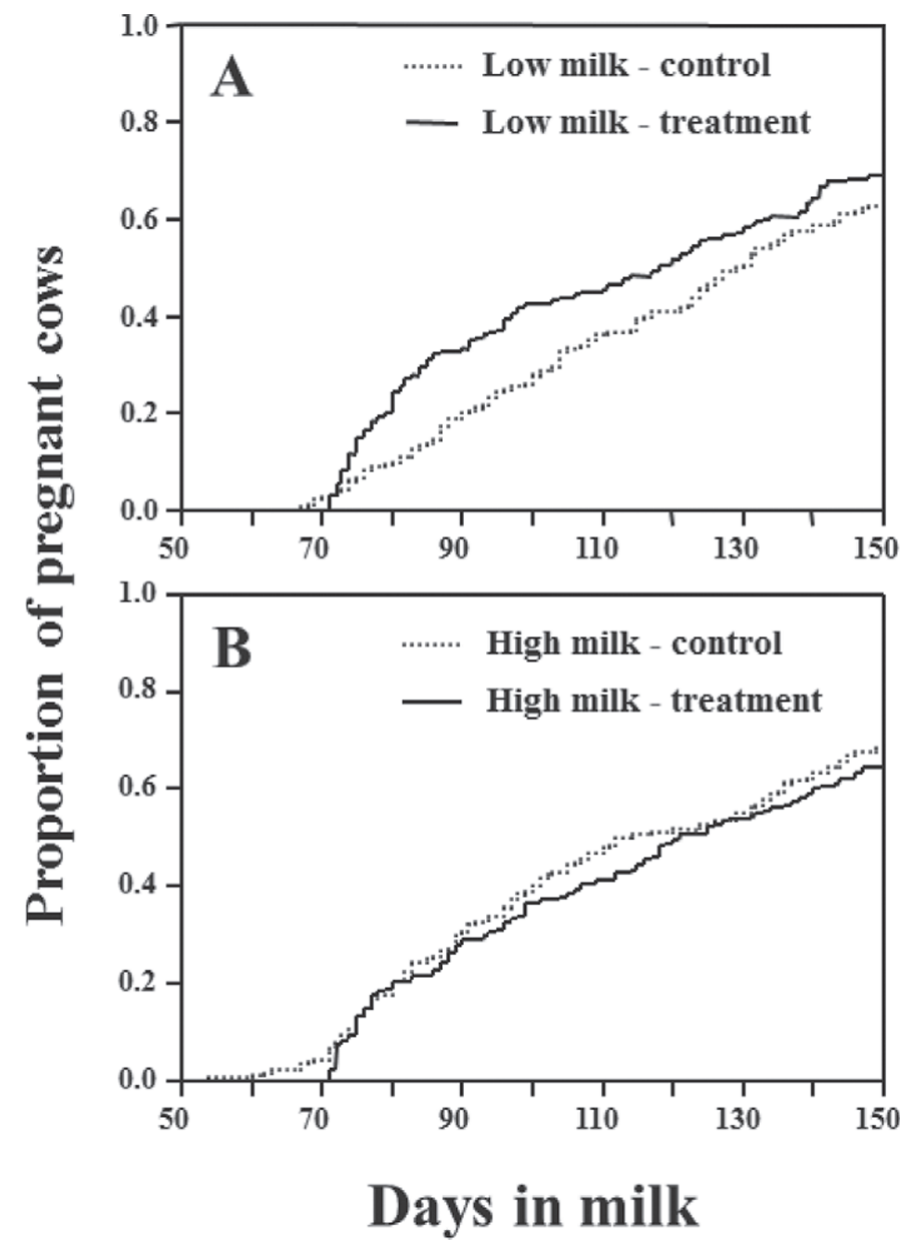

Figure 3. Survival curves for time to pregnancy. (A) Within the subgroup of cows with low milk yield (Low milk) pregnancy rate tended to be higher for treated cows relative to their control counterparts (log-rank test; $P=0.07$ ). (B) Within cows with high milk yield (High milk), pregnancy rate did not differ between treated and control cows. Milk yield $>48.0$ and $36.7 \mathrm{~kg} / \mathrm{d}$, for multiparous and primiparous cows, respectively, was defined high.

Here, we report for the first time that a combination of hormonal treatments before and after AI has a beneficial effect on fertility in cows with low BCS during the hot season. Nevertheless, the combined treatment only tended to increase $\mathrm{CR}$ in primiparous cows with a high BCS difference between calving and peak lactation. Moreover, administration of $\mathrm{GnRH}-\mathrm{PGF}_{2 \alpha}$ as the sole treatment improved $\mathrm{CR}$ in primiparous cows regardless of their BCS, cyclicity status, or both (Friedman et al., 2011). In light of these findings, the association between fertility, BCS, and the combined treatment warrants further attention.

The combined treatment also increased PR of cows with low milk production, the only variable that was associated in the current study with normal response to $\mathrm{GnRH}-\mathrm{PGF}_{2 \alpha}$ administration (i.e., expressed estrus 


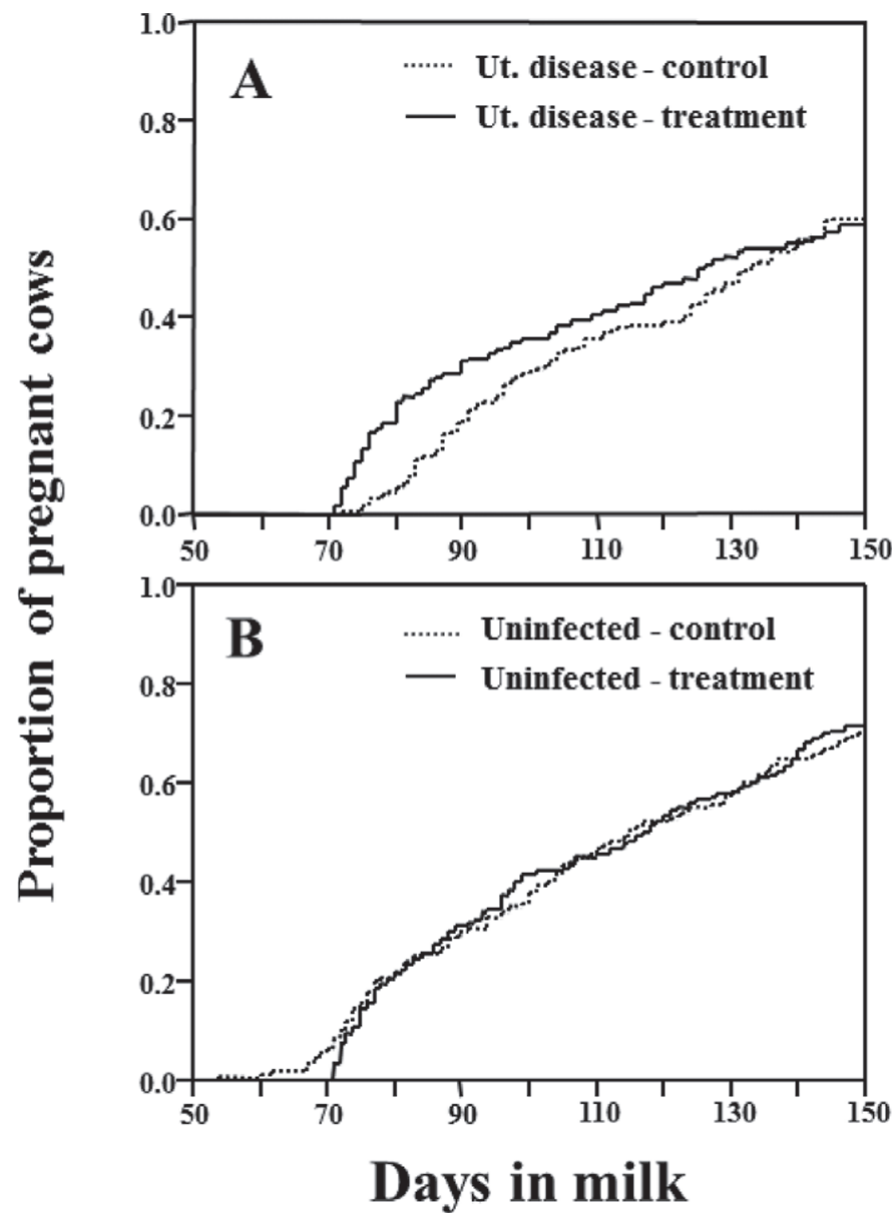

Figure 4. Survival curves for time to pregnancy. (A) Within the subgroup of cows with postpartum uterine disease (Ut. disease), pregnancy rate did not differ when cows contributed for the analysis $150 \mathrm{~d}$, and tended to be higher in the treated group relative to their control counterparts when cows contributed for the analysis $120 \mathrm{~d}$ (log-rank test; $P=0.086)$. (B) Within uninfected cows, pregnancy rate did not differ between treated and control cows.

within $5 \mathrm{~d}$ after the second administration of $\mathrm{PGF}_{2 \alpha}$ ). In agreement with this, low milk production was associated with a higher proportion of cows responding normally to 3 successive $\mathrm{GnRH}-\mathrm{PGF}_{2 \alpha}$ administrations (Friedman et al., 2011). Therefore, it seems that the beneficial effect of the combined treatment-reflected by increased PR 90 and PR 120 in cows with low milk production - is at least in part an outcome of the normal response to $\mathrm{GnRH}-\mathrm{PGF}_{2 \alpha}$ administration.

Of particular interest is the fact that 2 main diseases of dairy cows, mastitis (represented in the current study by high SCC) and uterine disease were influenced by the combined treatment in an opposite manner. Although the treatment improved fertility in cows with postpartum uterine disease, it negatively affected cows with high SCC. This contradictory response suggests that although both mastitis and endometritis disrupt uterine and ovarian functions (Sheldon et al., 2009b; Lavon et al., 2011), they probably act through different mechanisms. Endometritis has a direct effect on uterine function, thereby interfering with the normal embryo-maternal relationship in early pregnancy stages (Sheldon et al., 2009a). Endometritis has been reported to cause delayed resumption of cyclicity in cows (Fourichon et al., 2000; Opsomer et al., 2000), whereas the effect of mastitis on resumption of cyclicity is less clear. In addition, both endometritis (Bromfield and Sheldon, 2013) and mastitis (Lavon et al., 2010; Roth et al., 2013) are known to impair steroidogenesis in the preovulatory follicle, oocyte competence, and delay ovulation. However, the exact reasons for the negative treatment effect on cows with high SCC remain unclear.

To evaluate the magnitude of the combined treatment, we calculated the proportion of cows that were positively affected in terms of $\mathrm{CR}$ or $\mathrm{PR}$ at the $P<0.05$ level and compared it with the proportions revealed in our previous studies (Friedman et al., 2011, 2012). This included summation of 3 subgroups of cows: those diagnosed with uterine disease, those with low BCS at peak lactation, and those with low milk yield. Cows with high SCC that were negatively affected by the treatment were mathematically subtracted. Findings revealed that $52 \%$ of the cows were positively affected by the combined treatment, compared with $\mathrm{GnRH}-\mathrm{PGF}_{2 \alpha}$ $(37 \%)$ or CIDR $(36 \%)$ administration alone (Friedman et al., 2011, 2012). It seems that the combined treatment positively affected more cows. Nevertheless, this statement should be made with caution because treatments were not performed contemporaneously.

In summary, we suggest that summer reproductive management to alleviate the effects of heat stress should be based on intensive cooling combined with hormonal treatment. Given that different subgroups of cows benefit differently from the treatments, selective hormonal administration should be considered.

\section{ACKNOWLEDGMENTS}

The authors thank the teams of Chof-Hasharon, EinHachoresh, and Kedem dairy farms, Israel, for their skillful assistance. The work was supported by the Cattle Division of the Ministry of Agriculture, BeitDagon, Israel (Project \# 820-0299-12).

\section{REFERENCES}

Berman, A., and D. Wolfenson. 1992. Environmental modifications to improve production and fertility. Pages 34-126 in Large Dairy Herd Management. H. H. Van Horn and C. J. Wilcox, ed. American Dairy Science Association, Champaign, IL.

Bromfield, J. J., and I. M. Sheldon. 2013. Lipopolysaccharide reduces the primordial follicle pool in the bovine ovarian cortex ex-vivo and in the murine ovary in vivo. Biol. Reprod. 88:98. 
De Rensis, F., and R. J. Scaramuzzi. 2003. Heat stress and seasonal effects on reproduction in the dairy cow-A review. Theriogenology 60:1139-1151.

Flamenbaum, I., and N. Galon. 2010. Management of heat stress to improve fertility in dairy cows in Israel. J. Reprod. Dev. 56:S36$\mathrm{S} 41$.

Forro, A., G. Tsousis, N. Beindorff, R. Sharifi, L. Jaekel, and H. Bolwein. 2012. Combined use of Ovsynch and progesterone supplementation after artificial insemination in dairy cattle. J. Dairy Sci. 95:4372-4381.

Fourichon, C., H. Seegers, and X. Malher. 2000. Effect of disease on reproduction in the dairy cow: A meta-analysis. Theriogenology 53:1729-1759.

Friedman, E., Z. Roth, H. Voet, Y. Lavon, and D. Wolfenson. 2012. Progesterone supplementation postinsemination improves fertility of cooled dairy cows during the summer. J. Dairy Sci. 95:30923099 .

Friedman, E., H. Voet, D. Reznikov, I. Dagoni, and Z. Roth. 2011. Induction of successive follicular waves by gonadotropin-releasing hormone and prostaglandin $\mathrm{F}_{2 \alpha}$ to improve fertility of highproducing cows during the summer and autumn. J. Dairy Sci. 94:2393-2402.

Ghanem, M. E., T. Nakao, K. Nakatani, M. Akita, and T. Suzuki. 2006. Milk progesterone profile at and after artificial insemination in repeat-breeding cows: Effects on conception rate and embryonic death. Reprod. Domest. Anim. 41:180-183.

Goshen, T., and N. Y. Shpigel. 2006. Evaluation of intrauterine antibiotic treatment of clinical metritis and retained fetal membranes in dairy cows. Theriogenology 66:2210-2218.

Green, M. P., M. G. Hunter, and G. E. Mann. 2005. Relationships between maternal hormone secretion and embryo development on day 5 of pregnancy in dairy cows. Anim. Reprod. Sci. 88:179-189.

Hansen, P. J. 2013. Physiology and endocrinology symposium: Maternal immunological adjustments to pregnancy and parturition in ruminants and possible implications for postpartum uterine health: Is there a prepartum-postpartum nexus? J. Anim. Sci. 91:1639-1649.

Jordan, E. R. 2003. Effects of heat stress on reproduction. J. Dairy Sci. 86(E. Suppl.):E104-E114.

Kasimanickam, R., T. F. Duffield, R. A. Foster, C. J. Gartley, K. E Leslie, J. S. Walton, and W. H. Johnson. 2005. The effect of a single administration of cephapirin or cloprostenol on the reproductive performance of dairy cows with subclinical endometritis. Theriogenology 63:818-830.

Lavon, Y., E. Ezra, G. Leitner, and D. Wolfenson. 2011. Association of conception rate with pattern and level of somatic cell count elevation relative to time of insemination in dairy cows. J. Dairy Sci. 94:4538-4545.

Lavon, Y., G. Leitner, H. Voet, and D. Wolfenson. 2010. Naturally occurring mastitis effects on timing of ovulation, steroid and gonadotrophic hormone concentrations, and follicular and luteal growth in cows. J. Dairy Sci. 93:911-921.

Mann, G. E., G. E. Lamming, R. S. Robinson, and D. C. Wathes. 1999. The regulation of interferon-tau production and uterine hormone receptors during early pregnancy. J. Reprod. Fertil. 54(Suppl.):317-328.

Markusfeld, O., N. Galon, and E. Ezra. 1997. Body condition score, health, yield and fertility in dairy cows. Vet. Rec. 141:67-72.

Opsomer, G., Y. T. Grohn, J. Hertl, M. Coryn, H. Deluyker, and A. de Kruif. 2000. Risk factors for post partum ovarian dysfunction in high producing dairy cows in Belgium: A field study. Theriogenology $53: 841-857$.

Roth, Z. 2008. Heat stress, the follicle, and its enclosed oocyte: mechanisms and potential strategies to improve fertility in dairy cows. Reprod. Domest. Anim. 43(Suppl. 2):238-244.

Roth, Z., A. Bor, R. Braw-Tal, and D. Wolfenson. 2004. Carry-over effect of summer thermal stress on characteristics of the preovulatory follicle of lactating cows. J. Therm. Biol. 29:681-685.

Roth, Z., A. Dvir, D. Kalo, Y. Lavon, O. Krifucks, D. Wolfenson, and G. Leitner. 2013. Naturally occurring mastitis disrupts developmental competence of bovine oocytes. J. Dairy Sci. 96: 6499-6505.

Roth, Z., R. Meidan, A. Shaham-Albalancy, R. Braw-Tal, and D. Wolfenson. 2001. Delayed effect of heat stress on steroid production in medium-sized and preovulatory bovine follicles. Reproduction 121:745-751.

Santos, J. E., W. W. Thatcher, L. Pool, and M. W. Overton. 2001 Effect of human chorionic gonadotropin on luteal function and reproductive performance of high-producing lactating Holstein dairy cows. J. Anim. Sci. 79:2881-2894.

Sheldon, I. M., J. Cronin, L. Goetze, G. Donofrio, and H. J. Schuberth. 2009a. Defining postpartum uterine disease and the mechanisms of infection and immunity in the female reproductive tract in cattle. Biol. Reprod. 81:1025-1032.

Sheldon, I. M., S. B. Price, J. Cronin, R. O. Gilbert, and J. E. Gadsby. 2009b. Mechanisms of infertility associated with clinical and subclinical endometritis in high producing dairy cattle. Reprod. Domest. Anim. 44:1-9.

Souza, A. H., H. Ayres, R. M. Ferreira, and M. C. Wiltbank. 2008. A new presynchronization system (Double-Ovsynch) increases fertility at first postpartum timed AI in lactating dairy cows. Theriogenology 70:208-215.

Waldmann, A., O. Reksen, K. Landsverk, E. Kommisrud, E. Dahl, A. O. Refsdal, and E. Ropstad. 2001. Progesterone concentrations in milk fat at first insemination-Effects on non-return and repeatbreeding. Anim. Reprod. Sci. 65:33-41.

Wildman, E. E., G. M. Jones, P. E. Wagner, R. L. Boman, H. F. Troutt Jr., and T. N. Lesch. 1982. A dairy cow body condition scoring system and its relationship to selected production characteristics. J. Dairy Sci. 65:495-501.

Wiltbank, M. C., A. H. Souza, D. P. Carvalho, W. R. Bender, and B. A. Nascimento. 2011. Improving fertility to timed artificial insemination by manipulation of circulating progesterone concentration in lactating dairy cattle. Reprod. Fertil. Dev. 24:238-243.

Wolfenson, D., B. J. Lew, W. W. Thatcher, Y. Graber, and R. Meidan. 1997. Seasonal and acute heat stress effects on steroid production by dominant follicles in cows. Anim. Reprod. Sci. 47:9-19.

Wolfenson, D., Z. Roth, and R. Meidan. 2000. Impaired reproduction in heat-stressed cattle: Basic and applied aspects. Anim. Reprod. Sci. 60-61:535-547.

Wolfenson, D., H. Sonego, A. Bloch, A. Shaham-Albalancy, M. Kaim, Y. Folman, and R. Meidan. 2002. Seasonal differences in progesterone production by luteinized bovine thecal and granulosa cells. Domest. Anim. Endocrinol. 22:81-90.

Zeron, Y., A. Ocheretny, O. Kedar, A. Borochov, D. Sklan, and A. Arav. 2001. Seasonal changes in bovine fertility: Relation to developmental competence of oocytes, membrane properties and fatty acid composition of follicles. Reproduction 121:447-454 